臨床 高オルニチン血症，高アンモニア血症拉よび

$$
\text { ホモシトルリン疛症を呈する } 1 \text { 例 }
$$

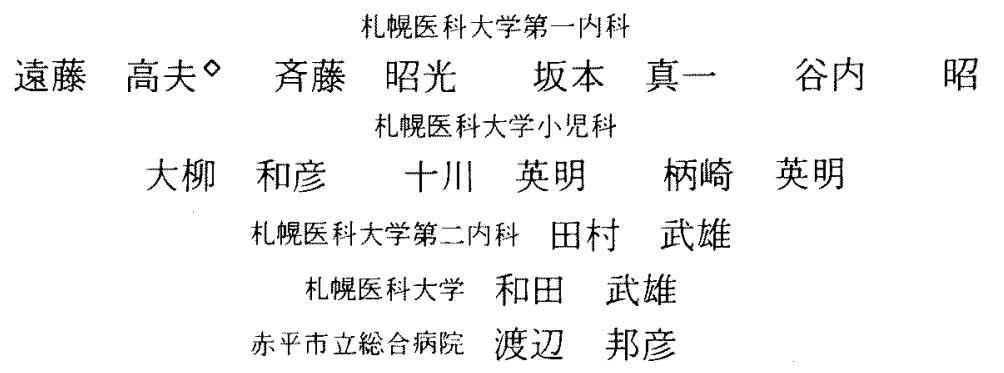

\title{
A CASE WITH HYPERORNITHINEMIA, HYPERAMMONEMIA AND HOMOCITRULLINURIA
}

Takao ENDo, MD, Akimitsu SaIto, MD, Shin-ichi SaKamoto, MD and Akira YaCHI, MD Department of Internal Medicine (Section I), Sapporo Medical College Kazuhiko Oyanagi, MD, Hideaki Sogawa, MD and Hideaki Tsukazaki, MD Department of Pediatrics, Sapporo Medical College

Takeo T AmURA, MD

Department of Internal Medicine (Section II), Sapporo Medical College

Takeo WADA, MD

Sapporo Medical College

Kunihiko WatanaBe, MD

Akahira City hospital, Akahira

概要 わが国初例と思われる高オルニチン血症, 高アンモニア血症怙よびホモシトルリン尿症 を呈する1例(41才，男)を経験した。 Shih et alの初例以来の報告8症例と比較し，本症の病態， 治療および早期猃断等について考察した。本例は遗伝素因は不明，小学時より知能低く，40才 時意識障害と高アンモニア血症を呈したことが契機となり発見された。、オルニチン経口負荷時 血中アンモニアの低下が注目された。 リジン経口負荷では著変なく，尿素サイクルの諸酵素活 性にも異常がみられなかつた，以上の所見上り，本例は従来の高アンモ二ア血症のI 型やII型 とは異なることが確認された。同様の既報例との比較では, 諸検査成績や電顕所見の上で多少 の相䞗点もあり, 病因病態解析上の課題が残されている.しかし文献的には本例と同様にオル ニチン負荷後血中アンモ二ア低下をきたす例むあり, 病因としてミトコンドリア膜に拈けるオ ルニチンの移送障害が推測されている。この考方方に基づき実施したオルニチン負荷療法では， 長期間血中アンモニアの低下が持続し，意識障害もみられず，この面での有効性が示された。 本例のよ5に, 軽症例では成人になつて発見される場合もあるので, 早期発見法の開発が望李 れるが，オルニチン誘導体3-aminopiperid-2-oneの尿中に括ける定性的検出が他の高オルニチ ン血症と同様に本症の発見にも役立つ可能性が指摘されている.

〔昭和54年6月16日 第131回北海道地方会推萀] 


\section{緒 言}

高オルニチン血症, 高アンモニア血症およびホ モシトルリン尿症を呈するてミ，酸代謝異常症

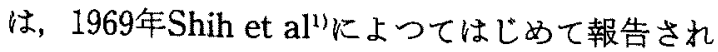
たが，現在までに数例を数点るに過ぎず2)3)，その 成因についてもまだ定説がない，わが国において は，このような症例はまだ報告が見当らない。

今回著者らは長期間の意識水準の低下と, 高了 ソモニア血症が契機となつて発見された 1 例を経 験した。過去の報告例と対比検討しながら，本例 の病因の解析や治療の可能性についても考察を加 吝て報告する。

\section{症例}

患者：41才, 男, 土建作業員.

主訴： 長期間の意識障害, 高アンモニア血症 および高オルニチン血症の精査.

家族歴：父は胃癌で66才時死亡，同胞は8人 で，第二子，第三子(共に男)は，それぞれ3才時 に死亡したが原因は不明，姝の子に発語遅缺児が いるが詳細は不明。他は健康。

既往歴およU゙生活歴：小学校入学以来学業成 績はクラスの最下位で，中学時代途中で通学をや めた。 27才の時工事中頭部打撲に上る硬膜外血腫 をきたし，血尰摘出術後，後遺症等はみられなか つたが，約10年間にわたりシフェニルヒダントイ ンを内服し，3年前に中止している。

現病歴：昭和53年8月15日, 後頭部痛と前胸部 の苦悶感を伴つた意識障害のため某病院に入院し たが，意識水準の低下は約 1 月間続いた。この間 同院にて高アンモ二ア血症があることが分かり， 低蛋白食やラクチニロース投与による改善もみら れないため，血漿のアミノ酸分析を行なつた。 そ の結果血墏中のオルニチンが高いことが分かり， 精査のため昭和53年10月5日当科へ転入院した。

入院時現症：身長 $152 \mathrm{~cm}$, 体重 $45 \mathrm{~kg}$ で体格は 小. 意識は清明. 皮䖉に黄疸なく，脈拍60/分，整， 緊張良好, 血王 $106 / 66 \mathrm{mmHg}$. 胸部は聴打診上異 常なし，腹部は右肋骨弓下に肝を1横指触知し，や や弾性硬。脾は触れない。浮腫や腹水貯留はない。 神経学的には，入院当日に一過性のはばたき振戦
を認めた以外は著変をみない。

入院時主要検査成績： 胸部X線写真，心電図 は著変なし、入院時の主な検査成績を表 1 亿示す が，血中アンモニアが $361 \mu \mathrm{g} / \mathrm{dl}$ （イオン交換樹脂 法）之異常高値を示す以外には著变はない，腎機 能，甲状腺機能，脳桷䯣液検査では異常はみられ なかつた。IQはWAIS知能検査で53と低下してい た。

血清アミノ酸分析：日本電子6-AH型アミノ 酸自動分析装置で測定し，結果を表2に示した。対 照に比べ，オルニチンが $644.6 \mathrm{nmol} / \mathrm{ml}$ と著しく 高いことが再確認された。

脳波所見： 徐波傾向を示すが，両側前側頭部 には鋭波および1ないし2秒間の3c/sの群波が時に みられた（図1）。

頭部の computed tomography：図2に示す ように，大脳括よび小脳の萎縮がみられる。

眼底所見：両眼共にDrusen様白点が散見さ 表 1。入院時主要検查成續

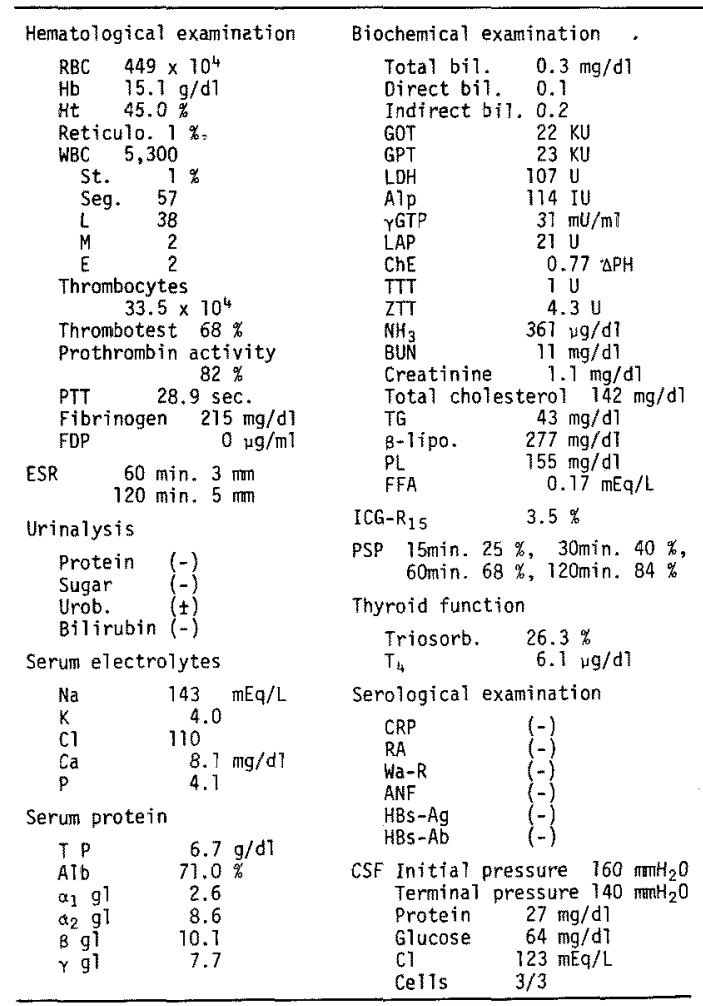


表 2，血清アミノ酸の分析成績

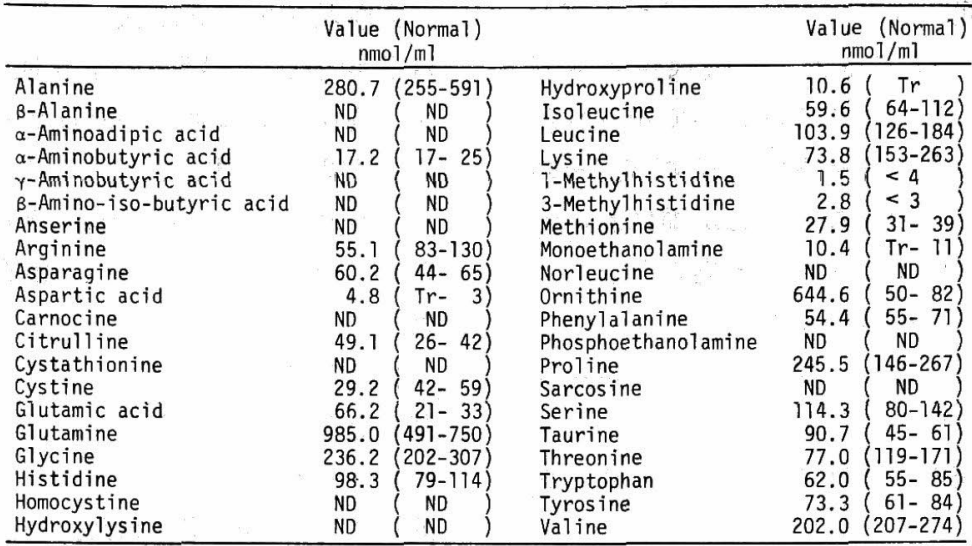

ND: not detected.

Tr: trace.

P4

図 1. 脳波所見

れる以外は著変はなかつた。

肝の腹腔鏡ならびに病理組織検査：肝表面は 平滑であるがや〉白調で，組織学的には，炎症反 応に乏しく, 一部のGlisson鞘や軽度の線維増生部 に少数の単核球浸潤を認めるにすぎない(図3).

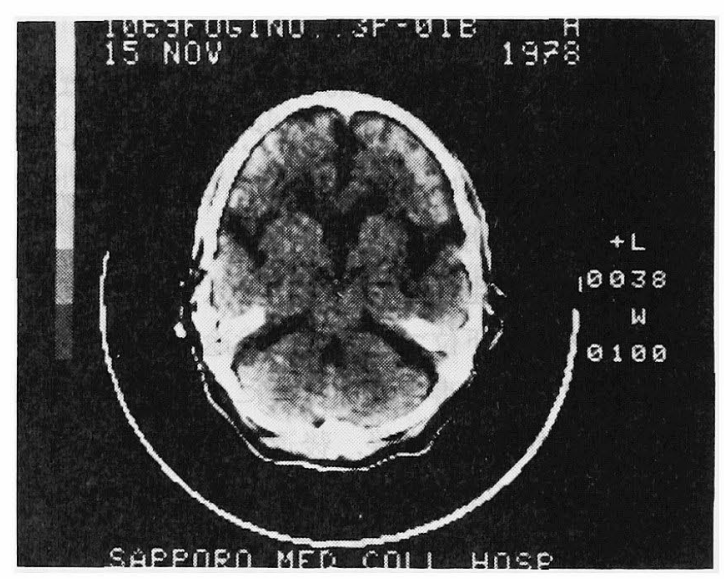

図 2. 頭部 computed tomography所見

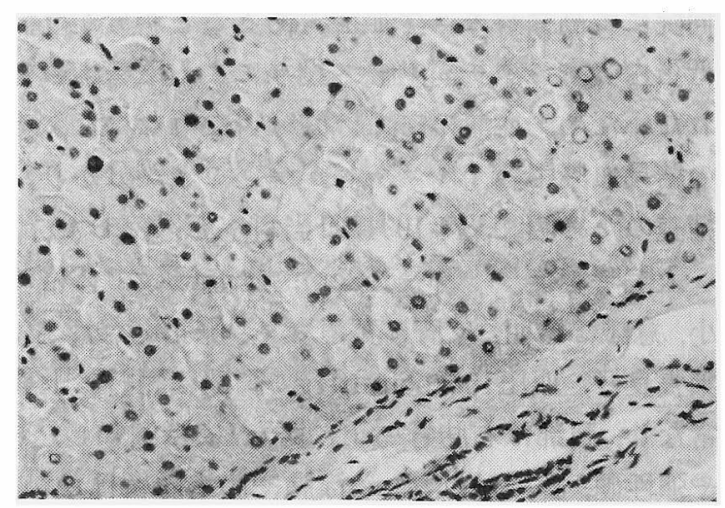

図 3. 生検肝組織, Hematoxylin-eosin染色. $\times 175$ 
A

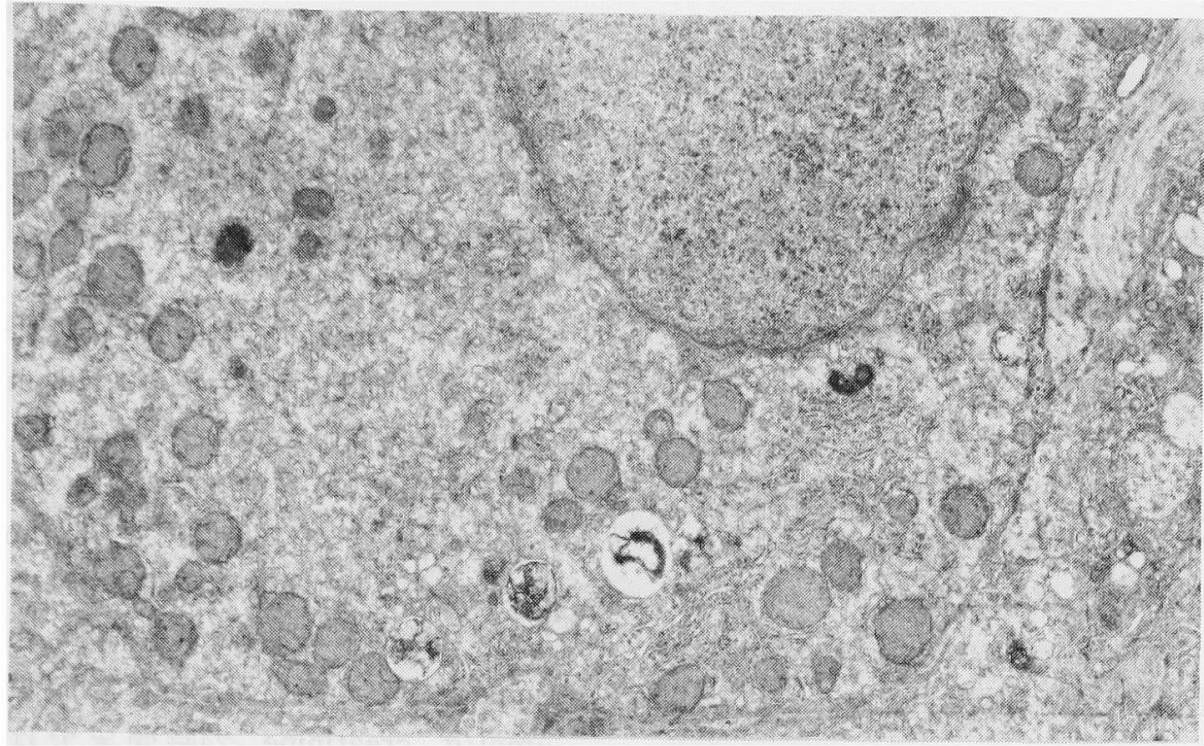

B

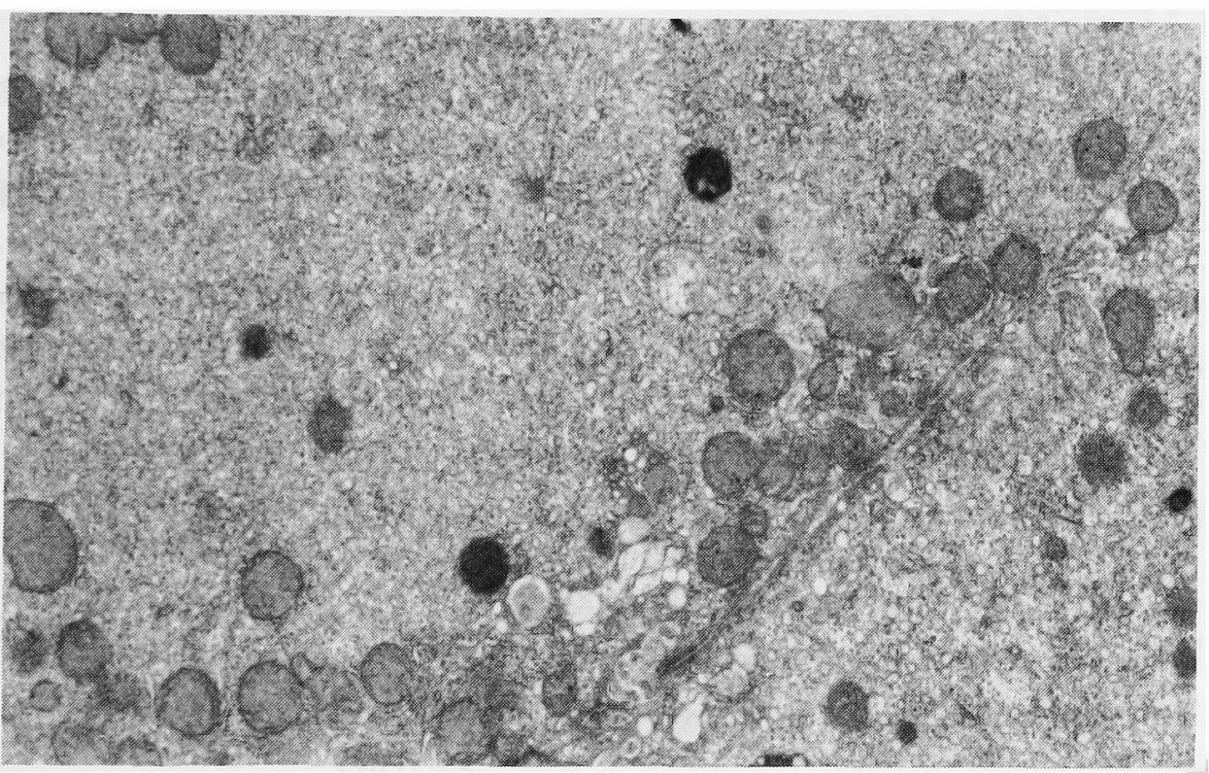

図 4 。生検肝の電子顕微鏡所見

A. 発達した滑面小胞体と比較的小型のミトコンドリアが目立つ。

B. A と同様だが, 滑面小胞体は肝細胞質の中央部に, ミトコンドリアは細胞質 辺縁に局在している。酷酸ウラニル，鉛二重染色， $\times 6,500$.

また小葉内には細胞質の明るい肝細胞が目立つ。 電顕的には, 肝細胞の滑面小胞体が著しく発達し， ミトコンドリアは比較的小型であるが著しい形態 異常は観察されない(図4A). 光見所見上の細胞質 の明るい細胞に一致して, 発達した滑面小胞体に 押されたように，ミトコンドリアが細胞の辺縁に
局在する所見が認められた（図4B）.

${ }^{99 m} \mathrm{~T}$ cスズコロイドによる肝シンチグラフィー および・99mTc HIDAによる胆道シンチグラ

フィー：特に異常は認められなかつた。

オルニチン経ロ負荷試験： L-オルニチン塩酸 $100 \mathrm{mg} / \mathrm{kg}$ を経口投与して血清中および尿中のア 

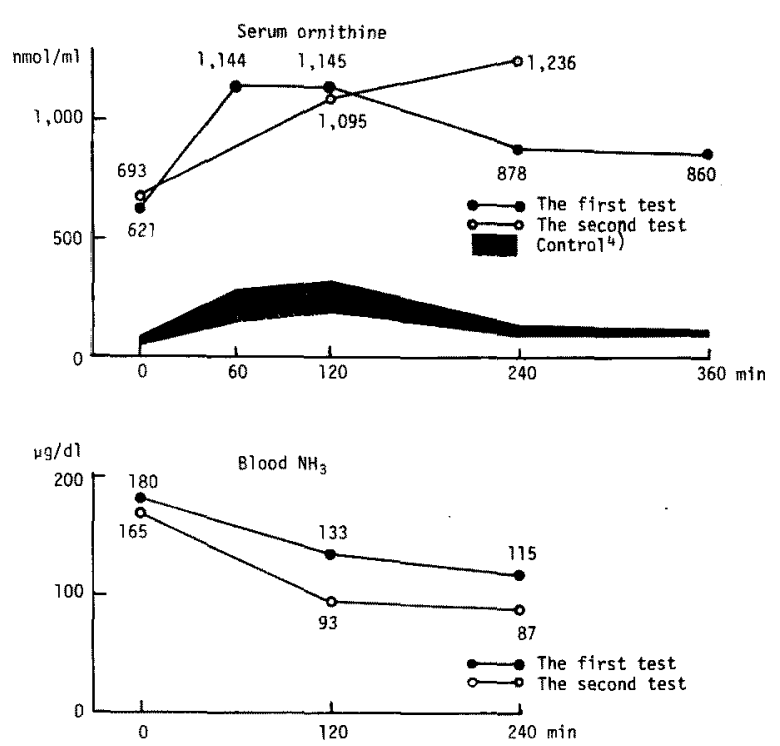

図 5.オルニチン経口負荷による泟清オルニチンお゙よ び直中アンもニアの変動

表 3、オルニチン経口負荷前後に持ける尿中アミノ酸 の変動 ( $\mu \mathrm{mol} / \mathrm{g}$ creatinine)

\begin{tabular}{|c|c|c|c|}
\hline & Before & 6 hours after & 24 hours after \\
\hline Alanine & 525 & 665 & 666 \\
\hline a-Aminoadipic acid & 50 & NT & 60 \\
\hline Arginine & NT & 8 & NT \\
\hline Asparagine & 70 & 77 & 84 \\
\hline Aspartic acid & 57 & NT & 55 \\
\hline Citrulline & 24 & 99 & 27 \\
\hline Cystine & 53 & 136 & 66 \\
\hline Glutamic acid & 48 & 67 & 62 \\
\hline Glutamine & 1,036 & 1,046 & NT \\
\hline Giycine & 927 & 826 & 1,007 \\
\hline Histidine & 617 & 923 & 352 \\
\hline Honocitrulline & 784 & 744 & 925 \\
\hline Isoleucine & 15 & 59 & 17 \\
\hline Leucine & 23 & 42 & 23 \\
\hline Lysine & 61 & 234 & 32 \\
\hline Ornithine & 118 & 975 & 105 \\
\hline Phenyla ?antne & 25 & 37 & 45 \\
\hline Serine & 439 & 509 & 499 \\
\hline Taurine & 604 & 1,108 & 844 \\
\hline Threonine & 154 & 198 & 195 \\
\hline Tyrosine & 123 & 102 & 130 \\
\hline Valine & 42 & NT & 48 \\
\hline
\end{tabular}

NT: not tested.

ミノ酸の変動と血中アンモニアの変動を検討すべ く，負荷前，後 $1,2,4$ 抢よび6時間目に採血し，ア ミノ酸分析とアンモニアの測定を行なつた ${ }^{2)}$. た尿は負荷前，負荷直後から6時間目（6時間尿） まで，さらに6時間目から24時間目(24時間尿上仮 称）までそれそれれ蓄尿し，分析に供した。対照に は大柳，十川らの既報》の例を用いた。

血清オルニチンは図5に示すように, 負荷前すで
に異常高值を示すが，負荷後著しく上昇し，6時間 後でも前值に復さなかつた。一方，アンモニアは， 前值が $190 \mu \mathrm{g} / \mathrm{dl}$ と高いが，2時間目 $133 \mu \mathrm{g} / \mathrm{dl} ， 4$ 時 間目には $115 \mu \mathrm{g} / \mathrm{dl}$ と次第に低下し注目された。そ の後第2回目の負荷試験を施行したが同様の変動 が確認された。

䍩のアミノ酸分析では，表3拈よび図6に示すよ $5 に$ ，負荷前既にオルニチンは $118 \mu \mathrm{mol} / \mathrm{g}$ crea tinineと異常高值を示すと共に，ホモシトルリン 排泄の異常増加が特徴的であつた.

尿中オルニチンは6時間尿で $975 \mu \mathrm{mol} / \mathrm{g}$ creatinine と著しく増加し，24時間尿ではほら゙前値に復 した。ホモシトルリンは負荷前 $784 \mu \mathrm{mol} / \mathrm{g}$ creatinine と極めて高いが，負荷後6時間尿では744 $\mu \mathrm{mol} / \mathrm{g}$ creatinine，24時間尿では $925 \mu \mathrm{mol} / \mathrm{g}$ creatinineとさらに排泄が増加した。

リジン経ロ負荷試験： L-リシン塩酸 $150 \mathrm{mg} /$ $\mathrm{kg}$ の経口負荷前後の血清中，抌よび㽷中の主なア ミノ酸の变動と血中アンモニアの変動を検査し た。

血清リジンは, 前値が図7のように60nmol $/ \mathrm{ml}$ と 対照 ${ }^{5)}$ に比較してや今低いが，負荷後の変動ハ ターンは対照 ${ }^{5}$ と注ら゙同様であつた。 また血清才 ルニチンは負荷前後で軽度の增加をみるのみであ
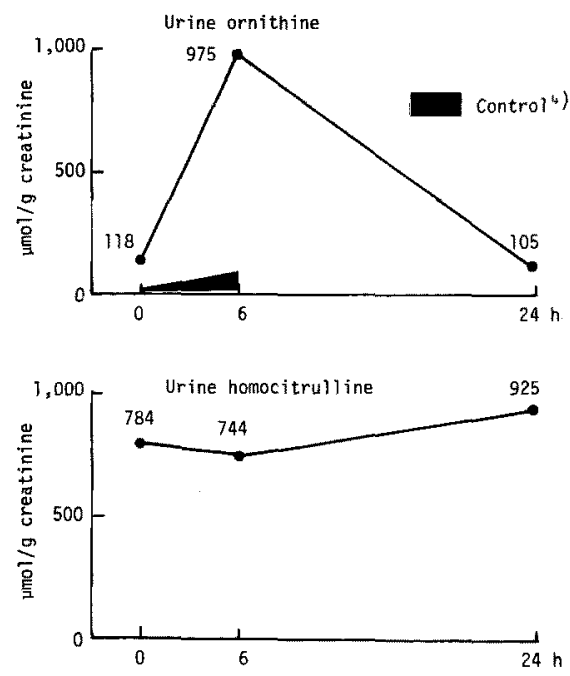

図 6。オルニチン経口負荷による尿中オルニチンおよ び尿中ホモシトルリンの変動 

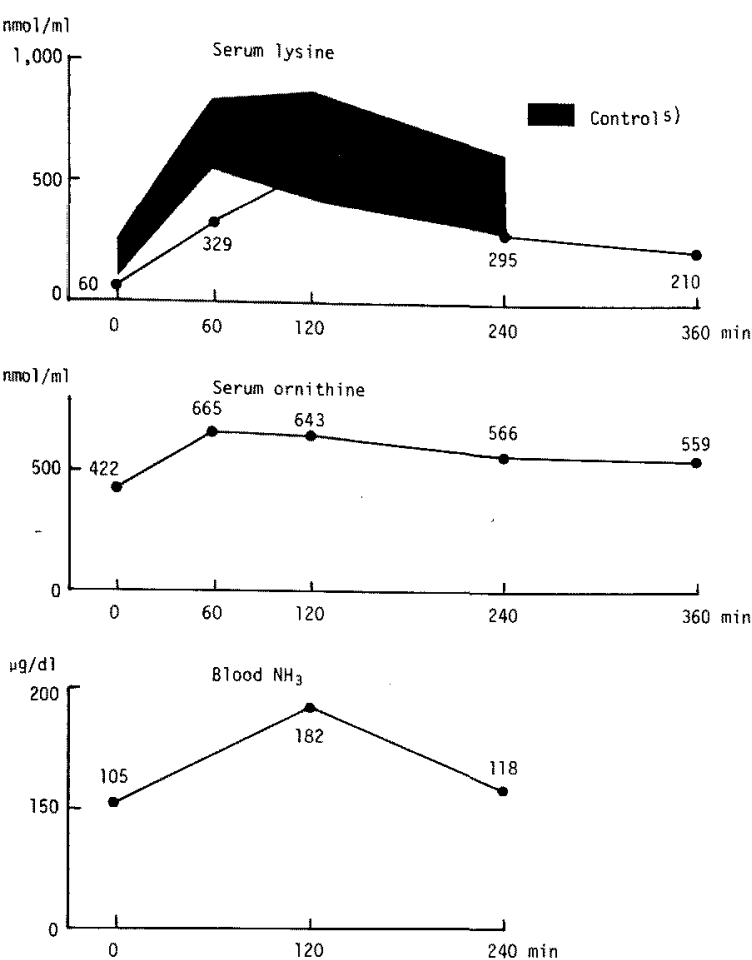

因 7.リジン経口負荷に上る血清オルニチンおよび血 中アンモニアの変動

表 4.リジン経口負荷前後における尿中アミノ酸の変 動 ( $\mu \mathrm{mol} / \mathrm{g}$ creatinine)

\begin{tabular}{|c|c|c|c|c|}
\hline & \multicolumn{2}{|c|}{ The present case } & \multicolumn{2}{|c|}{ Controls $(n=15)$} \\
\hline & Before & After & Before & After \\
\hline Arginine & 8 & 29 & $12-86$ & $13-83$ \\
\hline Cystine & 48 & 57 & $65-266$ & $73-247$ \\
\hline Honocitrulline & 806 & 864 & $30^{\star} \quad 31^{\star}$ & $22^{\star} \quad 58^{*}$ \\
\hline Lysine & 92 & 953 & $253-2,319$ & $184-3,219$ \\
\hline Ornithine & 71 & 307 & $17-138$ & $19-117$ \\
\hline
\end{tabular}

つた．さらに血中アンモニアは前値 $105 \mu \mathrm{g} / \mathrm{dl}$ に比 べ負荷後 2 時間で $182 \mu \mathrm{g} / \mathrm{dl}$ と上昇したが，4時間後 には $118 \mu \mathrm{g} / \mathrm{dl}$ と票前値に復した。

尿中の主なアミノ酸のリジン負荷前扣よび負荷 後6時間までの排泄を表4に示すが，負荷後はリジ ンのみならずオルニチンも増加を示した，尿中ホ モントルリンは，前值と同程度の異常高值が持続 し、リシン負荷による影響はほとんど認められな からた。

肝組織中の尿素サイクルに関する諸酵素活性の

測定： 開腹生検肝組織の一部について，尿素 サイクルに関する5種の酵素活性を測定した。すな わちcarbamyl phosphate synthetase I (CPS I) はNuzum and Snodgrass法6), ornithine transcarbamylase (OTC) はShimke法?), argininosuccinate synthetase (ASS) はKatoh et alの方法8), argininosuccisase (ASase) はNuzum and Snodgrass法6), arginase (ARG) はShimke法7)を用い て定量したが，これらは表5に示すように対照りに 比べて異常は認められなかつた。

治療に伴う血中アンモニアの変動： 血中アン モニアの測定は入院中は毎週2回，昼食をとらずに 午後1時に実施，退院後当初は週1回，次いで2 4 週に1回昼食抜きで午後1時に行なつた。

図8に示すように，入院後蛋白摄取量を $100 \mathrm{~g} /$ 日 から80g/日に減量したが，血中アンモニアの低下 傾向を示吉が，充分とはい〉難く，前述のように オルニチン経口負荷試験で血中アンモニア低下現 象を認めその治療応用への可能性を検討した。す

表 5 、䀒組織中に初ける尿素サイクル諸酵素の活性

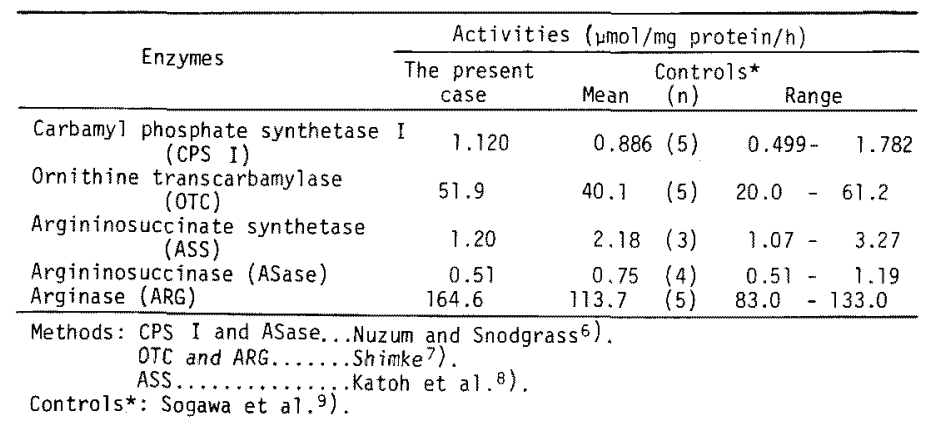




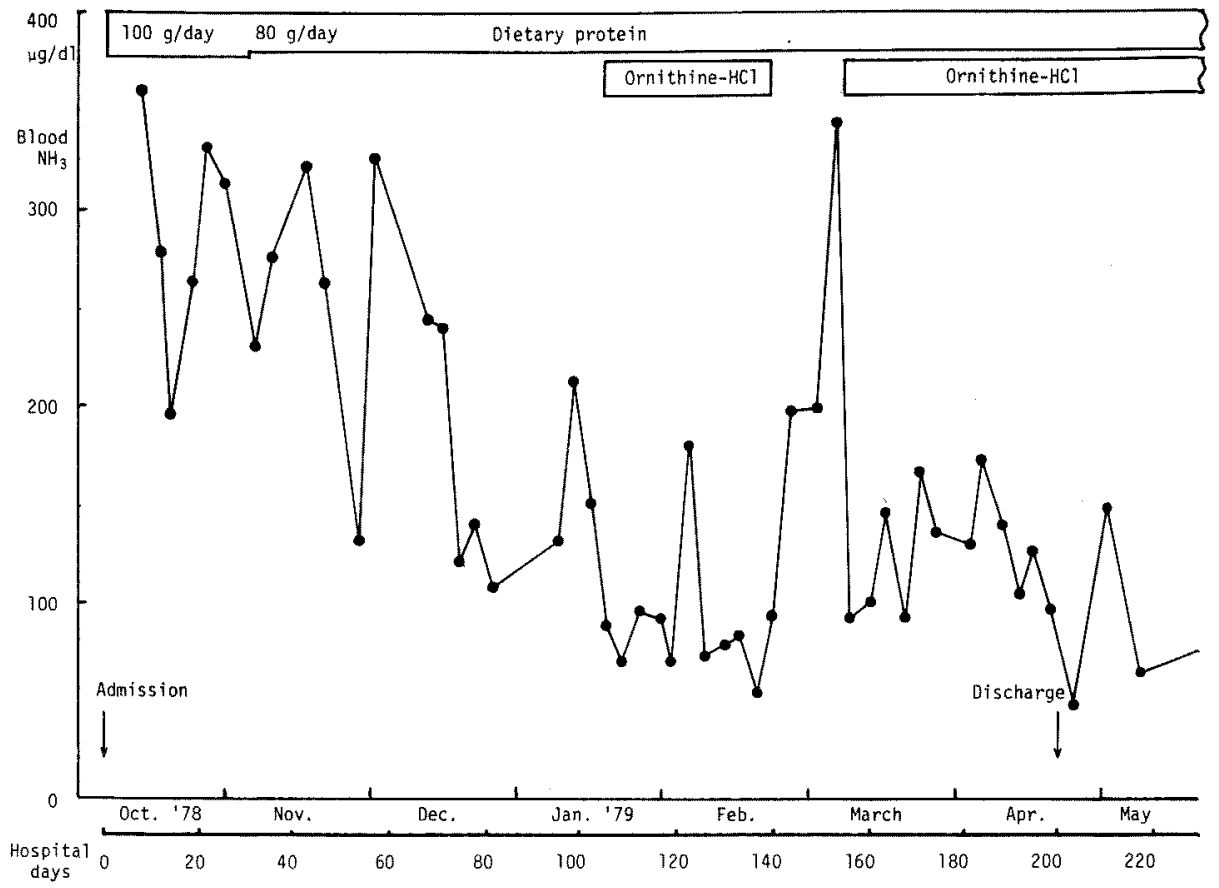

図8、治療に伴 ら血中アンモニアの変動

なわち，第106病日よりL-オルニチン塩酸塩を5g/ 日（オルニチンとして $3.9 \mathrm{~g} /$ 日）を毎日分3投与し たところ,血中フンモニアは著しく低下し， $53 \mu \mathrm{g} /$ dlを示した。しかし第142病日よりオルニチン投与 を一時中止したところ，血中アンモニアは急激に 上昇し， $345 \mu \mathrm{g} / \mathrm{dl}$ となつたため，第154病日より同 薬を再投与し，血中アンモニアの改善をみている。 第185病日から市販の ornithine-aspartateを投与 しているが，血中アンモニアは正常上界程度に安 定している。第200病日退院し，現在は軽ないし中 労作業に従事している。

\section{考案}

以上のよらな高オルニチン血症, 高アンモニア 血症拉よびホモシトルリン尿症を呈するアミノ酸 代謝異常症の1例を経験したが，次の3点に集約し て考察を加点る。

1）本例の病態および病因について

Shih et $\mathrm{al}^{11}$ が高オルニチン血症, 高アンモニア 血症怙よびホモシトルリン尿症を合併した1例を 報告して以来，同様の症例を明確に記載した報告
は少なく，著者らが調査した限りでは8例であ

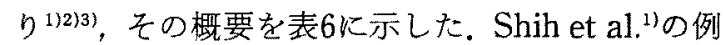
について，その病態を促来の高アンモニア血症と 比較すると血中OTCが正常であり，いわゆる高ア ソモニア血症II型のOTC欠損症とは異なり，また 高アンモニア血症 I 型のCPS欠損症に括いては, 血中オルニチンがornithine- $\alpha$-ketoacid transaminase (OKT) による代謝を受けるため血中に 増量しない点で異なることから，これを全く新し い型の高アンモニア血症であろうと考光た。さら にこの例に怙けるホモシトルリン尿症の原因に ついて，オルニチンはリシンより・- $\mathrm{CH}_{2}$ が1個少な いだけで構造上類似性が高いことから，OTCはり ジンも作用してホモシトルリンを合成する可能 性があり，尿中にも出現すると想定している。

本例に扣いても，肝組織中のOTCをはじめ CPS, ASS, ASase, ARG等の尿素サイクルに関連 した諸酵素は異常がみられない点で，いわゆる高 アンモニア血症のI型とは異なると考えられる。 また，オルニチン負荷後の血中オルニチンの变動 
表 6 ，報告例の概要

\begin{tabular}{|c|c|c|c|c|c|c|c|c|}
\hline Authors & & Age & Sex & $\begin{array}{c}\text { Ornithine } \\
\text { in serum } \\
\text { (nmol/m1) }\end{array}$ & $\begin{array}{c}\mathrm{NH}_{3} \\
\text { in biood } \\
(\mathrm{g} g / \mathrm{dl})\end{array}$ & $\begin{array}{l}\text { Homocitrulline } \\
\text { in urine } \\
\text { (umol/g } \\
\text { creatinine) }\end{array}$ & $\begin{array}{l}\mathrm{NH}_{3} \text { after } \\
\text { ornithine } \\
\text { loading }\end{array}$ & Clinical features \\
\hline Shin et al.1) & (1969) & $16.5 \mathrm{~m}$ & M & 915 & 150 & $58^{*}$ & No change & $\begin{array}{l}\text { Mental retardation } \\
\text { Myoclonic seizures }\end{array}$ \\
\hline Fell et al. ${ }^{2}$ ) & $(1974)$ & $27 y$ & $F$ & 630 & 200 & 130 & Decrease & $\begin{array}{l}\text { Mental retardation } \\
\text { Motor impairment }\end{array}$ \\
\hline \multirow[t]{6}{*}{ Gattfield et al. ${ }^{3}$ ) } & (1975) & $9 y$ & M & 550 & 270 & 270 & & $\begin{array}{l}\text { Mental retardation } \\
\text { Seizure }\end{array}$ \\
\hline & & $5 y$ & M & 330 & 252 & 732 & Decrease & $\begin{array}{l}\text { Mental retardation } \\
\text { Ataxia }\end{array}$ \\
\hline & & $17 y$ & $F$ & 380 & & 214 & & Norma] \\
\hline & & $31 y$ & M & 519 & 119 & 273 & & $\begin{array}{l}\text { Mental retardation } \\
\text { Seizure }\end{array}$ \\
\hline & & $22 y$ & $\mathrm{~F}$ & 430 & $n 1$ & 1,190 & & Norma' \\
\hline & & $19 y$ & M & 483 & 80 & 492 & & Norma 1 \\
\hline The present case & & $41 y$ & $M$ & 644.6 & 367 & 784 & Decrease & $\begin{array}{l}\text { Mental retardation } \\
\text { Unconciousness }\end{array}$ \\
\hline
\end{tabular}

* mg/day

パターンや，ホモシトルリン尿症の存在，低蛋白 食で血中アンモニアが低下㑯向を示したことなど は極めてShih et alの報告例"之類似している。し かし彼らの例では，オルニチン負荷後血中アンモ ニアの低下を認めていない点で，われわれの症例 と異なる。これに対し, Fell et alの報告例2では, オルニチン経口負荷により血中アンモニア值の低 下を認め，本例に一層類似している。

発症経過や症状の程度を比較すると，本例では 幼少時に扣いて症状が明確でなく，知能は低いが 日常生活には大きな支障をきたしていないし，意 識障害や振戦などの神経症状についても，成人に なつてから初めて出現して打り，これらの報告例 の間には症状発現の時期や程度に差がみられる。

Gattfield et $\mathrm{al}^{3)}$ 高オルニチン血症，高アンモ ニア血症打よびホモントルリン㽷症を是する1家 系6症例を報告し，常染色体性劣性遺伝形式の発症 を示すと考えているが，そのうら尿素サイクルに 関係した酵素を剆定した1例では，肝組織中の CPS Iが低下して扣り，本例とは多少異なつてい る.

またShih et $\mathrm{al}^{1) や F e l l ~ e t ~} \mathrm{al}^{2)}$ の例では，リジン 経口負荷により尿中へのホモシトルリンの排泄が 増加するのに対し，本例ではごく軽度の増加をみ るのみでこれが有意の変動とは判定し得なかつ た。
形態学的にも，Gattfield et $a \mathbf{l}^{3)}$ の例では，長い ミトコンドリア内に結晶様構造やcristaの長さの 異常や肥大, tubule等が観察されたりミミトコンド リ了基質中にbulge様構造物が認められたが，本例 ではミトコンドリアの軽度の小型化や細胞辺緣へ の偏在, 滑面小胞体の発達等の所見を示すのみで ある。

以上のよ5に, 高オルニチン血症, 高アンモ二 乃血症，ホモントルリン底症という共通所見を有 する諸症例の間には症状の発現程度や各種負荷試 験に対する反応態度，尿素サイクルに関係した醳 素活性值の上で多少の相違点が認められる。この 様な差は，各淀例が有する遺伝素丙の質的差に基 づくのか，あるい弾にその程度の差による現象 であるかは不明であり，今後の検討を要しよ5。

生化学的立場加病因について考察すると， Fell et $\mathrm{al}^{2)}$ の仮説は興味深く，また治療法の解明 の上でも注目される。すなわち，彼らの症例は本 例と最も共通点が多いが，オルニチン経口負荷で 血中アンモニアが低下することや，オルニチンが シトルリンになる反広がミトコンドリア内で行な われることを考觉ると，ミトコンドリア膜のオル ニチン通過炕障害が起これば， ミトコンドリア内 で永素サイクルの重要な基質の一つであるオルニ チン量が減少し，その結果アンモニア処理機構に 障害をきたし，高アンモニア血症が惹起されると 
している。これに加えて，オルニチンをグルタミ ン酸へと代謝するOKTもミトコンドリア内に存 在するため，この反応も低下することになり，そ の結果代謝されないオルニチンが血中に増量する と想定している.

さらにオルニチン負荷による血中アンモニアの 低下現象の機序については, ミトコンドリア外の オルニチン濃度を上げると濃度勾配によつてミト コンドリア内にオルニチンが入り，尿素サイクル の回転が円滑になり，アンモニアは処理されて低 下寸ると考察している。

以上の説は本例に扔いても，生化学レベルでの 成因を理解する上で極めて好都合な考方方々い文 よ5. Gamble et $\mathrm{al}^{10)}$ はラット肝についてではす るが，尿素合成の律速段階はオルニチンのミトコ ンドリア内へのunidirectional transportにあると 述べて括り，Fell et $\mathrm{al}^{2 /}$ の考方方を支持するるの である。この点本例に括いては， ミトコンドリア 分画中のオルニチンの定量やOKT活性の測定を 行ない,さらに吟味すべき課題が残されている。

\section{2）本例の治療の可能性について}

文献的には低蛋白食が用いられており，著者ら も1日の蛋白質拱取を常食の $100 \mathrm{~g}$ から $80 \mathrm{~g}$ 以下束 で減量した，この量の決定にあたつては，本例は 軽症と思われること，また肉体労働者であること を配慮し設定した。しかし罒8に示したように，血 中アンモニアは低下傾向がみられたが必ずしも満 足すべき成績と㛎言い難い。そこでFell et $\mathrm{al}^{2 /}$ の 考方方に基づいて，オルニチン経口負荷によるア ンモニア低下現象を治療に応用し，好成績を得た。 同治療の一時中断による急激な血中アンモニアの 上昇，さらにはオルニチン再投与による血中アン モニアの再低下を認めたことは，少なくとも血中 アンモニア值の改善といら点に関しては，本治療 法の有效性を示可所見と言党よ5. Fell et $\mathrm{al}^{21}$ の 例では，本法によりさらに精神神経学的所見の改 善もみられているが，本例では少なくとも本療法 開始後は，今回発見の系口となつた意識障害るみ られず，他の症例のような㾏挛なども認められな w.

\section{3）本症の早期発見法について}

前述の上うに各症例間には種々の相違点見出 されるゆ点，本症の概念は確立した段階にあると は言い難いが，類似症例中にはFell et $\mathrm{al}^{2 / や わ れ ~}$ われの例の上らに, 治療の可能性を有する例が含 まれている。このような例では早期発見, 早期治 療を行ならことにより，症状の進展を阻止し得る 可能性が高い. Shih et $\mathrm{al}^{11}$ やFell et $\mathrm{al}^{2}{ }^{2}$ が報告し た重症例では, 出生後早期に症状が明確に発現し ているのに対し，本例は症状が軽く，気付かれず に経過し，その発見は41才に拈いてである。この ような軽症例でも新生児期や幼少期にスクリーニ ング検㚗ができれば，今回のよらな姏置は早期に 行ならことができるはずである. Fell and Pollitt ${ }^{11}$ はこの点について, 高オルニチン血症患者の 尿中にはその誘導体である3-aminopiperid-2-one が増量し，この現象は本症でも認められること， さらにこの化合物は ninhydrin/collidine/acetic acid試薬 (1g ninhydrin, $700 \mathrm{ml}$ ethanol, $29 \mathrm{ml} \mathrm{2}$, 4,6-collidineおよび210 ml acetic acid）で夷白色 に呈色し，ゆつくりと紫色に変化することで定性 が可能なことを報告している，今後スクリーニン グ法として，本法が改善され使用されることを期 待したい。

\section{結語}

わが国では第1例と思われる高オルニチン血症， 高アンモニア血症，ホモシトルリン永症を合併す る1例を報告し，その病態扣よび病因，治療の可能 性, 早期発見法の開発等について考察を加えた。 な和本症例の概略は第131回内科学会北海道地方 会に拀いて発表したが，その後の二，三の検索成 績を加えてここに報告した。

\section{文献}

1) Shih VE et al: Hyperornithinemia, hyperam. monemia, and homocitrullinuria. Amer $\mathrm{J}$ Dis Child 117: 83, 1969.

2) Fell $V$, et al: Ornithinemia, hyperammonemia, and homocitrullinuria. Amer J Dis Child 127: 752, 1974.

3) Gattfield PD et al: Hyperomithinemia, hyperammonemia, and homocitrullinuria associated with decreased carbamyl phospate synthetase I 
activity. Pediat Res 9: 488, 1975.

4）大楖和彦, 他：高オル二チン血症の1例。臨小医 $25: 257,1977$.

5) Oyanagi $\mathrm{K}$ et al: Clinical and biochemical studies on periodic hyperammonemia with hyperlysinemia and homocitrullinuria. Tohoku J exp Med 120: 105, 1976.

6) Nuzum CT and Snodgrass PJ: Multiple assays for five urea-cycle enzymes in human liver homogenates. Grsolia S. Baguena R, \& Mayer F, ed. The Urea Cycle, John Wiley \& Sons, New York, 1976, p325.

7) Shimke RT: Adaptive characteristics of urea cycle enzymes in the rat. J Biol Chem 237: 459, 1962.

8) Katoh $\mathrm{H}$ et al: New radioisotopic assays of argininosuccinate synthetase and argininosuccinase. J Biochem 79 : 945, 1976.

9) Sogawa $\mathrm{H}$ et al: Periodic hyperammonemia, hyperlysinemia, and homocitrullinuria associ. ated with decreased arginiosuccinate synthetase and arginase activities. Pediat Res 11: 949, 1977.

10) Gamble JG et al : Transport of ornithine and citrulline across mitochondrial membrane. J Biol Chem 248: 610, 1973.

11) Fell V and Pollitt RJ: 3-aminopiperid-2-one, an unusual metabolite in the urine of a patient with hyperammonemia, hyperomithinemia and homocitrullinuria. Clin Chim Acta 87: 405, 1978. 